Acta Universitatis SAPIENTIAe

Agriculture And EnVIRONMENT, 13 (2021) 36-47

DOI: 10.2478/ausae-2021-0004

\title{
Sustainable and preservative historic garden management
}

\author{
Krisztina BÁLINT, ${ }^{1}$ Ildikó Réka BÁTHORYNÉ NAGY² \\ ${ }^{1}$ Department of Urban Planning and Urban Green Infrastructure, Hungarian University of \\ Agriculture and Life Sciences, Budapest, e-mail: b.krisztina1900@gmail.com \\ ${ }^{2}$ Department of Urban Planning and Urban Green Infrastructure, Hungarian University of \\ Agriculture and Life Sciences, Budapest, e-mail: Bathoryne.Nagy.Ildiko.Reka@uni-mate.hu
}

Manuscript received 15 June 2021; revised 30 June 2021; accepted 12 July 2021

\begin{abstract}
The restoration of historic gardens in Hungary puts an increasing responsibility on the shoulders of management. The use of what might be termed as "traditional horticultural approach" significantly increases the needs and costs of garden maintenance. But if we do not fulfil this task, heritage value can be lost and the former restoration efforts can become futile. Today's challenge is to find a balance between these two issues. This study aims to develop the scientific foundations for practical solutions.
\end{abstract}

Keywords: heritage protection, maintenance, green space management, research methodology

\section{Introduction}

The status of historic gardens in Hungary has changed significantly over the last two decades. The possibilities for the research and restoration of these often damaged and fragmented gardens were relatively limited in the past, but thanks to the funding by the European Union, more than 20 gardens were restored between 2007 and 2013 [1]. Now 18 further sites have the chance for restoration (at least the surroundings of mansions) by the National Mansion and Castle Programme [2]. From the perspective of designed landscapes, the main preservation task is clearly the restoration of the spatial structure. It means that the garden areas that were neglected and afforested over the last century have to be cleaned of the overgrowth in order to reveal the visual structure of the gardens thereby [3]. From this practical fact and the fundamental idea that specifies gardens as living, plantbased creations follows that constant management and maintenance is essential in the conservation of the garden heritage [4]. 
Reviewing the daily practice and the Hungarian literature on green space management and maintenance [5], it becomes clear that currently the horticultural approach and technologies are the methods used for the conservation of the garden heritage. These works, regardless of their intensity, usually appear in the management as an expense. The increased areas, following the restoration works, also have to be maintained, so the resources of maintenance tasks have to be increased as well. This phenomenon sets up a difficult situation for the management because maintenance work cannot be done with tight financial background, and it can lead to loss of heritage value and waste of restoration work. Solving this problem is a huge practical challenge. For the development of a widely applicable solution, a proper scientific foundation can serve as a great aid. Therefore, the authors' collaborative research is aimed to find landscape architectural tools for heritage protection by sustainable maintenance. This article introduces the basic methodology of the topic.

\section{Materials and methods}

In order to examine the methods of the so-called conservative and sustainable management of historic gardens, which is the aim of the research, it is necessary to analyse the basic materials of the study. Thanks to the variety of historic garden styles and their different management needs, the research is limited to designed landscapes, also called English gardens, which are located on the historical territory of Hungary. One of the reasons of the narrowed focus of the study is the composition of the Hungarian historic gardens. The majority of historic gardens are English style in our country, so the results will be widely applicable to develop practical solutions. Another important reason is the idea of designed landscapes: these aim at creating idealized landscapes, where humanity and nature can cooperate in harmony [6]. English landscape gardens seem to be optimal models for investigating the issue of sustainable management since the idealized landscape is characterized by closeness to nature, based on ecological principles, to which the human use is added. Human use appears in the form of the agriculture of the $19^{\text {th }}$ century, whereby the management solutions of today are expected to correspond to this. Besides the economic and ecological aspects, the artistic factor is a further main element as a social need. These components of sustainability clearly appear in the ideology of designed landscapes. After defining the material of the research, we had to study the restoration processes. The conclusion that can be drawn from experiences of restoration practices is that one of the most significant tasks is the restoration of spatial structure: to define and recreate the ratio of historical grasslands and woodlands and the composition from the neglected structure [7]. The maintenance of the restored structure is one of the most crucial components of the preservation. That is why the research narrows further the focus to gardens with restored spatial structure or where the spatial structure is well preserved. 
After the recognition of adequate research materials, in order to define the garden's management structure, firstly we had to develop a methodology. What can be considered as heritage value in a garden? How can we differentiate the maintenance intensity needs of different parts of a garden? Which are the parts of a garden where near sustainable technologies can be applied?

This paper describes the development of methodology, with one sample site analysis, and the evaluation of the research approach. The site that has been chosen for this study is the park of the Andrássy Mansion in Betliar, Slovakia.

\section{Results and discussions}

In order to develop the methodology, first of all it is necessary to define the elements and definitions of the topic, i.e.: What we mean by sustainable management in heritage conservation? What methods can be used to explore it?

In the research, by the term "management", we mean a general, connected system that operates the whole site, which the garden is part of, and by the term "maintenance" we mean the professional tasks, the utilized technologies, and the adopted processes to take care of the garden.

Whether talking about classical, horticultural or comprehensive, sustainable management (which became more significant in the days of urbanization and climate change) [8], the need for the management of gardens is essential because of their duality: on the one hand, it is a man-made object and on the other it is a natural and living creation [9]. Historic garden management adds a new layer to this principle, whereby garden management is not only important because of its function, recreation, or representation but also essential in the conservation of historic values; ergo conservational management is in fact the basic form of management with regard to historic gardens. As explained earlier in the introduction, there is a need for increased management due to restoration, which requires more resources in practice than what are realistically available. If we think about the gardens' former role, we can easily formulate the answer to why it is so challenging to get enough resources for maintenance today. The gardens were once the ornamental gardens of a family with a prosperous manorial background. As an ornamental garden, its maintenance was a general expense that could be financed by the economic prosperity of the same manor or the financial background of the family. It is also important that the technology and manpower of its maintenance was also partially available by the agricultural staff of the manor [10]. Nowadays, this economic integrity of the manors and such financial background is lost. Thereby, the maintenance of the gardens is a societal responsibility given by their historic significance. The proper financing of their management without adequate resources requires us to find sustainable solutions. Therefore, we need to explore how we can understand sustainability 
in the context of garden management and maintenance. For this part of the study, the identification and representation of the three pillars of sustainability proved to be the right choice.

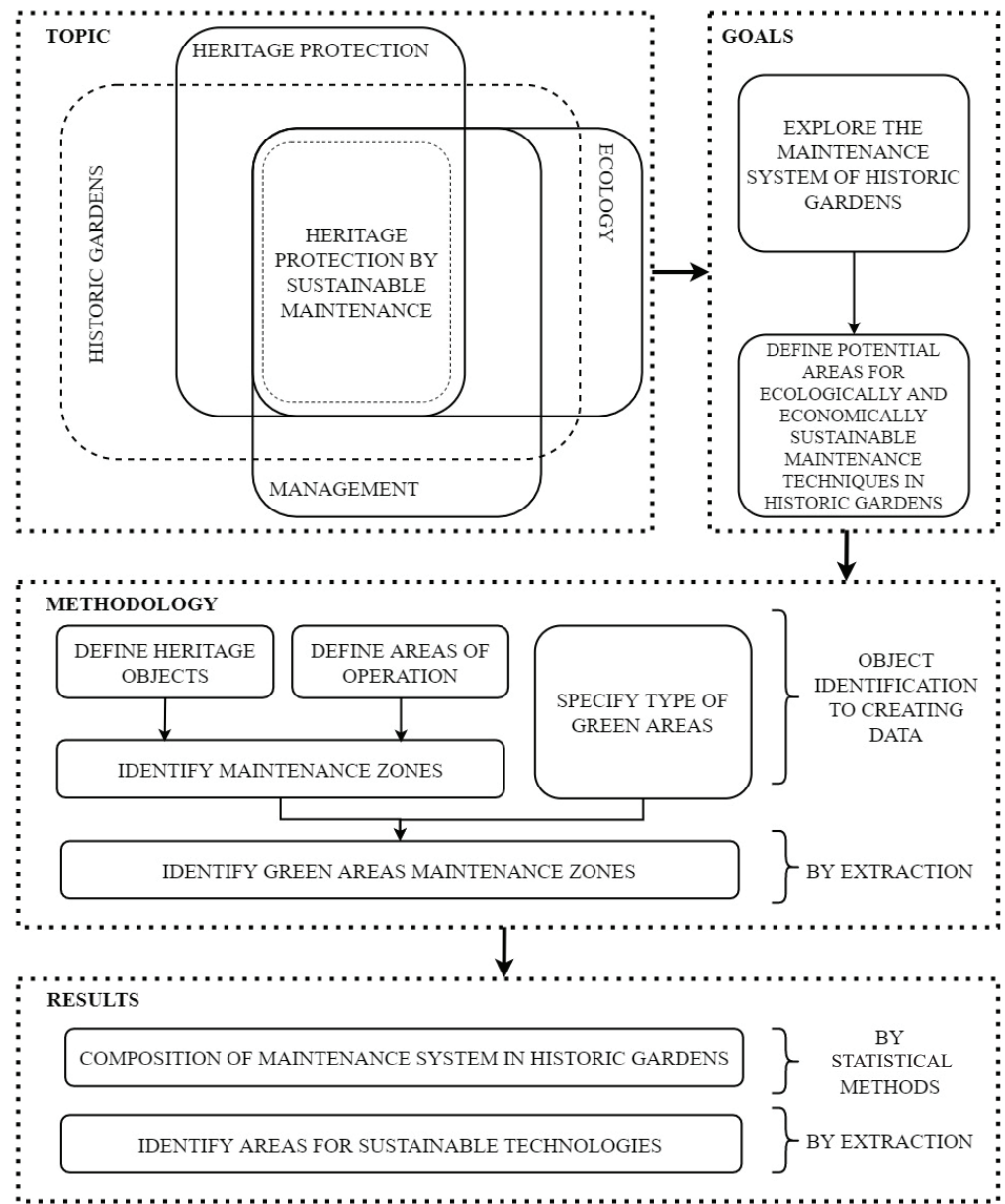

Figure 1. Methodology

The societal pillar of sustainability is clearly justified by the historical value of the gardens, based on the Florence Charter: "A historic garden is an architectural and horticultural composition of interest to the public from the historical or artistic point of view" [4]. Accordingly, maintenance is essential from a societal point of view, so the preservative management and maintenance of these values, in an authentic way, has become one of the priorities of the research. The economic aspect of sustainability means maintenance technologies, which demand fewer 
resources and can be profitable by sustainable agricultural practices or forestry [11] and also can have a beneficial effect on the management background from the aspects of finance or tourism. It is important to note that the parks were never, not even in their brightest times, self-sustaining; ergo this cannot be expected nowadays [12]. Finally, there is the aspect of ecological sustainability. This can be measured mainly by the effects of maintenance technologies applied on the semi-natural habitats.

The above detailed, basic context will define the primary research questions for the sample site analysis, which tries to specify and identify the current maintenance structure of the parks in order to detect the potential areas where alternative solutions, which are both economically and ecologically sustainable, can be applied while preserving heritage value. To formulate answers to these questions, we have collected data via field surveys and through analysing maps. The base map on which the quantitative elements can be identified was created by measurable orthophotos [13], which include the canopy level, and by an official land registry map, which determines the boundary of the sample site.

In order to describe the site's maintenance system, as a first step it is necessary to identify the objects with historical, functional, or operational interest and their environment. These surfaces are identified as shown in Table 1, whether talking about buildings and their surrounding areas, pleasure grounds, walkways, garden structures, other structures, sports grounds, offices, or accommodations.

Subsequently, also according to Table 1, the surfaces are classified into three categories according to the maintenance needs of historic gardens: Intensive Maintenance Category 1 was given to the representational surfaces with high priority, which included the surroundings of the mansion, the pleasure ground and its flowerbeds, and other bedding areas in its vicinity. Additional historic objects, operational objects, walkways (irrespective of their paving) and their surroundings are classified as Intensive Maintenance Category 2. Finally, the remaining green areas are classified as Extensive Maintenance Category. The definition of the surrounding areas of each object was based on two criteria: firstly, by adaptation to the historical structure of the garden, which depends on the situation on the site, and, secondly, by a practical maintenance need of the green surfaces, which is simplicity and does not require any unique preparation before the actual work. In the study, if there are not any other features, the surrounding area means 1 mower track width $(1.25 \mathrm{~m})$ along walkways, garden structures and 2 mower track width $(2.5 \mathrm{~m})$ next to buildings. Some elements were not examined in this study due to their specific maintenance needs, namely buildings, and the water system. 
Table 1. Classification of park elements

\begin{tabular}{|c|c|c|c|c|}
\hline Component & I. Int. & II. Int. & Ext. & Unm. \\
\hline mansion & & & & $\mathrm{X}$ \\
\hline $\begin{array}{l}\text { mansion environment } \\
\text { (paved surface defined by historical structure) }\end{array}$ & $\mathrm{X}$ & & & \\
\hline $\begin{array}{l}\text { pleasure ground } \\
\text { (perennials, annuals, hedges, lawn, and } \\
\text { shrubs) }\end{array}$ & $\mathrm{X}$ & & & \\
\hline $\begin{array}{l}\text { other flowerbed } \\
\text { (perennials, annuals, hedges, lawn, and } \\
\text { shrubs) }\end{array}$ & $\mathrm{X}$ & & & \\
\hline $\begin{array}{l}\text { walkways } \\
\text { (solid pavement, gravel, or without pavement) }\end{array}$ & & $\mathrm{X}$ & & \\
\hline $\begin{array}{l}\text { lanes along walkways } \\
\text { (1 riding mower track width) }\end{array}$ & & $\mathrm{X}$ & & \\
\hline $\begin{array}{l}\text { garden structures with historical value } \\
\text { (e.g.: ornamental pool, well, etc.) }\end{array}$ & & $\mathrm{X}$ & & \\
\hline $\begin{array}{l}\text { environment of garden structures with } \\
\text { historical value } \\
\text { (according to the historical structure, and } 2 \\
\text { riding mower track width) }\end{array}$ & & $\mathrm{X}$ & & \\
\hline $\begin{array}{l}\text { other garden structures } \\
\text { (storage, operational buildings, etc.) }\end{array}$ & & $\mathrm{X}$ & & \\
\hline $\begin{array}{l}\text { environment of other garden structures } \\
\text { (according to the use, and } 2 \text { riding mower } \\
\text { track width) }\end{array}$ & & $\mathrm{X}$ & & \\
\hline $\begin{array}{l}\text { buildings with historical value } \\
\text { (pavilion, staffage buildings, waterfalls, etc.) }\end{array}$ & & & & $\mathrm{X}$ \\
\hline $\begin{array}{l}\text { environment of buildings with historical value } \\
\text { (according to the historical structure, and } 2 \\
\text { riding mower track width) }\end{array}$ & & $\mathrm{X}$ & & \\
\hline $\begin{array}{l}\text { operational buildings } \\
\text { (office building, accommodation, etc.) }\end{array}$ & & & & $\mathrm{X}$ \\
\hline $\begin{array}{l}\text { environment of operational buildings } \\
\text { (according to the use, and } 2 \text { riding mower } \\
\text { track width) }\end{array}$ & & $\mathrm{X}$ & & \\
\hline grasslands & & & $\mathrm{X}$ & \\
\hline \multicolumn{5}{|l|}{ tree-shaded grasslands } \\
\hline woodlands with three levels of vegetation & & & $\mathrm{X}$ & \\
\hline water system and its equipment & & & & $\mathrm{X}$ \\
\hline
\end{tabular}


By mapping and classifying the objects and their surrounding areas into management classes, the created surfaces can highlight the management composition of the garden. This way, these components became measurable. In the following paragraphs, the study focuses on the green areas of the garden. Because of the principles described earlier, the research is mainly concerned with the spatial structure of the garden, which is defined by the woodlands and grasslands. Thus, once the management composition of the gardens has been defined, it will become possible to find further answers to our research questions. The next step is the classification of green surfaces.

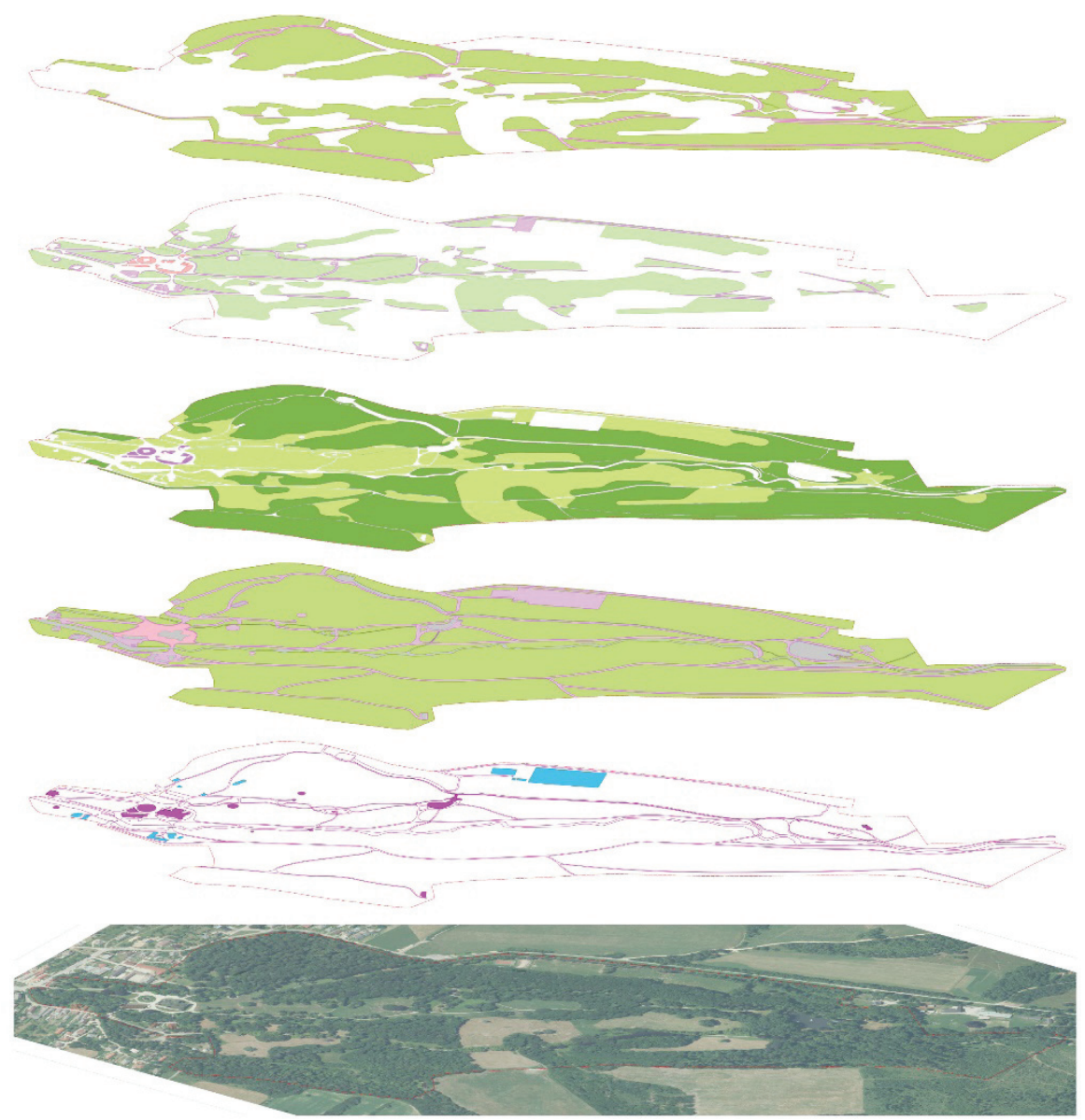

Figure 2. Differentiating and mapping the green surfaces and maintenance zones 
The green surfaces are divided into three categories: ornamental planting, grasslands, and woodlands with three levels of vegetation. This categorization mirrors the ground-level surfaces, but the addition of a layer for trees will be later necessary to complete the methodology. For example, some historical tree specimens can be located on extensive surfaces and still require intensive care.

Table 2. Specifications of green areas

\begin{tabular}{|c|c|c|c|}
\hline AREA & $\begin{array}{l}\text { ORNAMENTAL } \\
\text { PLANTING }\end{array}$ & GRASSLANDS & $\begin{array}{c}\text { WOODLANDS WITH } \\
\text { THREE LEVELS OF } \\
\text { VEGETATION }\end{array}$ \\
\hline $\begin{array}{l}\text { Green areas of the } \\
\text { garden according to } \\
\text { the cadastral map } \\
\text { and current usage }\end{array}$ & $\begin{array}{l}\text { Annuals, } \\
\text { perennials, } \\
\text { lawn, hedges, } \\
\text { floral shrubs, } \\
\text { etc. }\end{array}$ & $\begin{array}{l}\text { Surfaces where } \\
\text { grass maintenance } \\
\text { technologies are } \\
\text { currently applied }\end{array}$ & $\begin{array}{l}\text { Surfaces with } \\
\text { woodland character, } \\
\text { where trees, } \\
\text { shrubberies, and } \\
\text { ground vegetation live } \\
\text { together and where } \\
\text { grass maintenance } \\
\text { technologies cannot be } \\
\text { applied }\end{array}$ \\
\hline $499,091 \mathrm{~m}^{2}$ & $1,922 \mathrm{~m}^{2}$ & $\begin{array}{c}179,300 \\
\mathrm{~m}^{2}\end{array}$ & $\begin{array}{c}318,059 \\
\mathrm{~m}^{2}\end{array}$ \\
\hline
\end{tabular}

Conclusions can be drawn from the study by dividing the maintenance zones, examining the composition of the vegetation, and, finally, overlapping the vegetation and management zone surfaces. We can easily understand the maintenance structure and the green surfaces of the whole site on the map and draw the conclusion: a significant part of the garden can be managed extensively while preserving the historical values.

Table 3. Maintenance zones of the park

\begin{tabular}{|c|c|c|c|}
\hline AREA & INT. MAN. CAT. 1. & INT. MAN. CAT. 2. & EXT. MAN. CAT. \\
\hline $\begin{array}{l}\text { Garden area } \\
\text { according to } \\
\text { the cadastral } \\
\text { map and } \\
\text { current usage }\end{array}$ & $\begin{array}{l}\text { Areas with } \\
\text { significant historical } \\
\text { value: mansion } \\
\text { environment, } \\
\text { pleasure grounds, and } \\
\text { related elements }\end{array}$ & $\begin{array}{l}\text { Areas of historical } \\
\text { elements around the } \\
\text { park and every other } \\
\text { surface with regular } \\
\text { usage: walkways and } \\
\text { their environments, } \\
\text { operational areas, etc. }\end{array}$ & $\begin{array}{l}\text { Other green surfaces } \\
\text { where sustainable } \\
\text { approaches can be } \\
\text { examined }\end{array}$ \\
\hline $566,411 \mathrm{~m}^{2}$ & $5,663 \mathrm{~m}^{2}$ & $58,072 \mathrm{~m}^{2}$ & $\begin{array}{c}472,040 \\
\mathrm{~m}^{2}\end{array}$ \\
\hline
\end{tabular}


As Table 2 shows, only $1 \%$ of the management zone distribution requires Intensive Maintenance Category 1. Functional areas, environments with secondary importance, historical and operational areas represent only $10.3 \%$. In contrast, extensive management zones constitute $83.3 \%$ of the garden area. Looking at the zonal distribution of green areas, as shown in Table 3, we can see the dominance of built elements on both intensively managed surfaces. Only $0.4 \%$ of the total greenery of the managed areas belong to Intensive Maintenance Category 1 and only $5.1 \%$ belong to Intensive Maintenance Category 2, while $94.6 \%$ of green spaces require extensive management.

Table 4. Maintenance zones of green surfaces

\begin{tabular}{|c|c|c|c|}
\hline AREA & INT. MAN. CAT. 1. & INT. MAN. CAT. 2. & $\begin{array}{c}\text { EXT. MAN. } \\
\text { CAT. }\end{array}$ \\
\hline $\begin{array}{l}\text { Green areas } \\
\text { of the garden } \\
\text { according to } \\
\text { the cadastral } \\
\text { map and } \\
\text { current usage }\end{array}$ & $\begin{array}{l}\text { Green areas with } \\
\text { significant historical } \\
\text { value: surfaces with } \\
\text { annual, perennial, } \\
\text { lawn, hedges, floral } \\
\text { shrubs, etc. }\end{array}$ & $\begin{array}{l}\text { Green surfaces near historical } \\
\text { elements around the park } \\
\text { and every other surface with } \\
\text { regular usage: lane along } \\
\text { walkways, environments of } \\
\text { historical and operational } \\
\text { buildings, etc. }\end{array}$ & $\begin{array}{l}\text { Other green } \\
\text { surfaces where } \\
\text { sustainable } \\
\text { approaches can } \\
\text { be examined }\end{array}$ \\
\hline $499,091 \mathrm{~m}^{2}$ & $\begin{array}{c}1,923 \\
\mathrm{~m}^{2}\end{array}$ & $25,627 \mathrm{~m}^{2}$ & $\begin{array}{c}472,040 \\
\mathrm{~m}^{2}\end{array}$ \\
\hline
\end{tabular}

Whether we look at the total park area or the green areas, both intensively managed areas have halved in terms of green surfaces. The extensive area is stagnating or increasing in proportion, which is not surprising since the intensive areas are designated along built structures because of heritage preservation. Overall, the intensive green management is only needed on $5.5 \%$ of the whole site. From these results, we can formulate an answer for one of the research questions (which is also the base of the doctoral research), and we can describe the maintenance structure of the garden. Before we present the next analysis, we emphasize the principles that intensively managed areas require traditional management to preserve their value, while extensively managed areas may be suitable for the alternative types of technologies that promote economic and ecological sustainability.

Regarding the classification (Table 2) of green areas, in the park of Betliar, only $0.4 \%$ are ornamental plantings, and $35.9 \%$ are open grasslands and grasslands with solitaire trees or clumps. The bulk of the garden is woodland with three levels of vegetation, which makes up $63.7 \%$. Looking at the classifications and analyses, it is not surprising that whether we talk about grasslands or woodlands, the extensive form of management appears on the most extensive areas. 
Table 5. Ornamental plantings (with lawn) and grasslands by management zones

\begin{tabular}{cccc}
\hline AREA & $\begin{array}{c}\text { INT. MAN. } \\
\text { CAT. 1. }\end{array}$ & INT. MAN. CAT. 2. & \multicolumn{1}{c}{ EXT. MAN. CAT. } \\
\hline & $\begin{array}{l}\text { Lawns in } \\
\text { ornamental } \\
\text { planting } \\
\text { compositions }\end{array}$ & $\begin{array}{l}\text { Grass surfaces } \\
\text { where the usage } \\
\text { or historical value } \\
\text { demands continuous } \\
\text { maintenance }\end{array}$ & $\begin{array}{l}\text { Actual grasslands where alternative } \\
\text { technologies and ecological } \\
\text { approaches can be applied without } \\
\text { changing the historical structure }\end{array}$ \\
\hline $\begin{array}{c}181,223 \\
\mathrm{~m}^{2}\end{array}$ & $\begin{array}{c}1,922 \\
\mathrm{~m}^{2}\end{array}$ & $\mathbf{1 . 1 \%}$ & $\begin{array}{c}14,060 \\
\mathrm{~m}^{2}\end{array}$ \\
\hline
\end{tabular}

In the case of grasslands, ornamental plantings are included in the Intensive Grass Maintenance Category 1 since intensively maintained lawns play a significant role in their composition and are present on only $1.1 \%$ of the grasslands. From the perspective of the study, the proportion of perennial and annual surfaces can be neglected. Intensive Grass Maintenance Category 2 is applied on $7.8 \%$ of grasslands. These two surfaces will require a horticultural approach in the further studies on applicable technologies. On extensive surfaces, alternative methods can be examined that, according to other international and national experiences, are ecologically and economically sustainable, e.g. correctly timed mowing or traditional grazing. Intensive Woodland Maintenance Category 1 cannot be found at all due to the nonrepresentative attributes of woodlands. Only a relatively low proportion, 3.6\%, requires intensive approach according to the study methodology. This means that on $96.4 \%$ of the woodland areas, extensive, sustainable management can be applied. In order to provide economic sustainability and increase management resources, the applicability of sustainable forestry is also worth examining.

Table 6. Woodlands with three levels of vegetation by management zones

\begin{tabular}{|c|c|c|}
\hline AREA & INT. MAN. CAT. 2. & EXT. MAN. CAT. \\
\hline & $\begin{array}{l}\text { Woodland edges where the usage } \\
\text { or historical value demands } \\
\text { maintenance }\end{array}$ & $\begin{array}{l}\text { Actual woodlands where alternative } \\
\text { technologies, forestry, and ecological } \\
\text { approaches can be applied }\end{array}$ \\
\hline $318,059 \mathrm{~m}^{2}$ & $11,445 \mathrm{~m}^{2}$ & $306,661 \mathrm{~m}^{2}$ \\
\hline
\end{tabular}

\section{Conclusions}

The presented methodology proved to be suitable to identify the management composition of a historic garden, which is fundamental to create a scientific approach for management issues. The methodology can serve as a basis for future scientific research. By the evaluation of the work, we can declare that a further 
development of the methodology is needed. The integration of the historic trees will form an additional layer. After this addition, the next phase of the research will be the application of the research methodology on several other sample sites. (Currently, three other locations are planned.) The results are expected to vary to a certain extent - such is the case of the proportion of grasslands and threelayered vegetation, depending on the restoration level of the spatial structure. Some deviations can be expected in the percentages of management zones, depending on the size of the parks.

Predictably, the summary of all the future analysis results of the sites will show an average, approximate area where alternative, sustainable maintenance technologies can be applied. Once the surfaces and their characteristics have been determined, a comparison of different technologies is the next planned phase of the research. By these technologies, we mean the earlier mentioned sustainable, correctly timed mowing, sustainable, traditional grazing, and sustainable forestry based on international experiences [14]. This part of the research will be based primarily on literature on grassland management and forestry, supplemented by interviews with farmers, foresters, and green space managers who use similar technologies. Finally, these methods will be compared according to their estimated work hour requirements and to the expected semi-natural habitat values as a result of maintenance technologies.

\section{Acknowledgements}

The research was supported by the Hungarian University of Agriculture and Life Sciences, Institute of Landscape Architecture, Urban Planning and Garden Art, Department of Urban Planning and Urban Green Infrastructure.

We are grateful to Gábor Alföldy for providing the land registry map and to Miklós László Pap for the help in the English translation.

\section{References}

[1] https://www.palyazat.gov.hu/tamogatott_projektkereso (2021.01.20). EU2007-2013, KEOP-3.1.3/2F/09 and KEOP-3.1.3./2F/09-11.

[2] http://nkvp.hu/ (2021.01.20).

[3] Szikra, É. (2000), A tájképi kertek rekonstrukciós, helyreállítási lehetőségei és módszerei. In: Galavics, G. (ed.), Historic gardens in and around Hungary. Studies on research and restorations. Budapest: MTA Múvészettörténeti Kutatóintézete - MÁGUS Kiadó. 116-126.

[4] ICOMOS, Florence Charter 1. §. In: Fejérdy, T. (ed.), Karták könyve. Budapest: Építésügyi Tájékoztatási Központ Kft. 
[5] Kiácz, Gy., Szendrői, J. (1980), A zöldfelületek fenntartása. Budapest: Mezőgazdasági Kiadó.

[6] Buttlar, A. (1989), Der Landschaftsgarten Gartenkunst des Klassizismus un der Romantik. Köln: DuMont.

[7] Alföldy, G. (2013), Történeti kertek a változás küszöbén. Múemlékvédelem LVII(6). Budapest: Forster Gyaula Nemzeti Örökséggazdálkodási és Szolgáltatási Központ. 385-399.

[8] Báthoryné Nagy, I., Gergely., A., Bálint., K. (2019), Fenntartható és klímaadaptív városi gyepfenntartás Veszprém közterületein (2016-18) és annak hatása a gyepek diverzitására. In: Fazekas, I., Lázár. I. (eds.), Tájak múködése és arculata. Debrecen: MTA DTB Földtudományi Szakbizottság. 337-342.

[9] Ormos, I. (1955), A kerttervezés története és gyakorlata. Budapest: Kiadó.

[10] Bálint, K. (2020), A gyömrői Teleki-kastély parkjának története a kezelés tükrében. In: Fodor, M., Bodor, P. (eds.), SZIEntific meeting for young researchers Budapest: Szent István University. 81-92.

[11] Viszló, L. (ed.) (2012), A természetkímélő gyepgazdálkodás: hagyományőrzó szemlélet, modern eszközök. Csákvár: Pro Vértes Természetvédelmi Közalapítvány.

[12] Takács, K. (2017), Uradalmi kertészetek a 19. századi Magyarországon. Doctoral dissertation. Budapest.

[13] https://www.geoportal.sk/ (2020), Orthophoto.

[14] Watkins, J., Wright, T. (eds.) (2007), The management \& maintenance of historic parks, gardens \& landscapes - The English heritage handbook. London: Frances Lincoln. 